\title{
Obraz Bratislavy v českých cestopisech meziválečného období
}

\author{
Jana Pátková
}

PÁTKOVÁ, J.: The Image of Bratislava in Czech Travelogues of the Interwar Period

SLOVENSKÁ LITERATÚRA, vol. 68, 2021, no. 3, pp. 235-245

DOI: https://doi.org/10.31577/slovlit.2021.68.3.3

ORCID ID: 0000-0002-1780-5046

Key words: travelogue, imagology,

Czech-Slovak relations,

Czechoslovak Republic

The paper focuses on the literary representations of Bratislava in Czech travelogues and formulates various narratives of those depictions of the city that are related to the establishment of the Czechoslovak Republic in 1918. The paper compares Karel Kálal's and Ivan Hálek's travelogues of the so-called pre-coup period - the period before 1918 - with texts of the same genre written during the First Czechoslovak Republic (Jakub Deml, Josef Váchal, Karel Čapek, Marie Majerová, S. K. Neumann). The travelogues drew attention to the traditional culture of Slovaks (represented by Karel Plicka's photographs) and sought new forms of Czech-Slovak relations in the political atmosphere of the so-called Czechoslovakism. Bratislava, which entered new cultural relations with the establishment of the new republic, occupied a specific place in these. The reconstruction of the image of Bratislava in the analysed texts shows that it did not become the main symbol of the changes that took place after 1918. The travelogues represent it only marginally and Bratislava corresponds to the perspective of the socalled null morpheme. The article employs the theory of imagology and, marginally, also theories of postcolonialism.

Klúčové slová: cestopis, imagologie, 

znik Československé republiky přinesl v českém kulturním prostředí ve srovnání s předchozími obdobími zcela odlišný typ zájmu o Slovensko, které se po roce 1918 ocitlo v nových geopolitických i kulturních souvislostech. Novou pozici mohla hypoteticky zaujmout také Bratislava, ale její př́běh měl v české cestopisné tvorbě specifické postavení. Historický zlom i vyhrocený střet odcházejících kultur s novou státní mocí, to vše předurčovalo Bratislavu k tomu, aby se stala hlavním symbolem změny, která nastala v souvislosti se začleněním Slovenska do nového státního útvaru. $V$ cestopisné tvorbě českých autorů se tak nestalo. Namísto nového obrazu města zůstává významotvorná trhlina, která se konfliktně rozevírá. Bratislava má na stránkách českých cestopisů i románů spíš marginální zastoupení. Škála důvodů je poměrně rozsáhlá a sahá hlouběji do minulosti.

Podstata literárních stereotypů a obrazů o Slovensku se fixovala nejen na stránkách umělecké literatury, ale i v dokumentárních a polodokumentárních žánrech ještě před rokem 1918. Důležitou roli sehrály také bedekry a cestopisy. ${ }^{1}$ Dominantní v nich byl venkovský prostor, př́rodní krásy Tater, jen ojediněle se předmětem zobrazení stal život ve městě. ${ }^{2}$ Poznávání městského života v průběhu 19. století viditelně zaostávalo za bohatým literárním zpracováním př́rodních krás. Zcela příznakově byla minimální pozornost věnována dnešnímu hlavnímu městu, které v českých cestopisných textech vystupovalo pod rozmanitými historickými názvy, jež generovaly další významy: Prešpurk - Pozsony - Bratislava. Kromě svého elementárního významu odrážejí jednotlivé názvy také rozmanité narativy ${ }^{3}$ prosazující se v českých cestopisech at už viditelně či jen okrajově. Obraz Prešpurku je součástí staršího slovakofilského narativu, ${ }^{4}$ který se anachronicky prosazuje ještě ve dvacátých letech 20. století. K mad'arskému názvu Pozsony odkazují autoři jen tehdy, když chtějí v ironickém modu formulovat nesouhlas s politikou jednotných Uher. Literární reprezentace slovenské Bratislavy už v sobě skrývá aktualizační př́vlastky prosazujícího se čechoslovakismu.

Charakter a rozsah změn bratislavského narativu, které nastaly po roce 1918 v zobrazování Bratislavy, dokumentuje i materiál cestopisných textů. Hypoteticky by se dalo předpokládat, že největší posun nastal právě na pozadí nejvýraznějšího společensko-politického zlomu. Konkrétní obraz Bratislavy se však problematizuje konkrétní realitou, ve které byla vzájemná znalost Čechů a Slováků v době vzniku první republiky ještě stále velmi nízká. $Z$ tohoto důvodu si nezanedbatelná část cestopisů uchovává i po roce 1918 osvětový charakter slovakofilského narativu, do kterého vstupuje už narativ nový, utvářený ideou čechoslovakismu, která se snažila legitimizovat vznik společné republiky. Náznak skutečné změny přichází až mnohem později.

1 Zřejmá je elasticita žánru, která rozšiřovala repertoár cestopisů o další varianty na pomezí umělecké a dokumentární literatury. Např́klad cestopisná reportáž, povídky a romány s cestopisným jádrem.

2 Přednost měla města se slovenským etnikem, například Turčiansky Svätý Martin nebo Liptovský Mikuláš.

3 Viz použití termínu narativ u Jozefa Tancera: ,Jednotlivé skupiny si vytvárajú a presadzujú svoj vlastný obraz o meste, t. j. svoj špecifický príbeh-naratív“ (Tancer 2013: 138).V souvislosti s cestopisnou tvorbou českých autorů je zř̌ejmé, že se vztahuje v dané podobě jen ke slovakofilskému narativu. Ostatní reprezentace mají spišs solitérské zastoupení s individualizovaným jazykem, nikdo další na jejich cestopisnou tvorbu už nenavázal.

4 Díky slovakofilské tradici pevně ukotvené v české kultuře na přelomu století se čeští čtenáři seznamovali se slovenskou krajinou i kulturou už v předválečném období. 
Zájem českých slovakofilů o Slovensko před rokem 1918 se formoval na stránkách cestopisů do podoby faktografického, nacionálního i uměleckého popisu země našich nejbližších sousedů. $V$ průsečníku těchto tří aspektů je možné analyzovat jednotlivé literární reprezentace Bratislavy před rokem 1918. Jedná se o tyto stěžejní cestopisy předpřevratového období: cestopis Rudolfa Pokorného (Z potulek po Slovensku, 1883), osvětové texty s cestopisným přesahem a uměleckou ambicí od Karla Kálala (kolektivní sborník Od Šumavy k Tatrám, 1898; Na krásném Slovensku, 1903; Slovensko a Slováci, 1906) a bedekr Stanislava Klímy (Vlakem přes Slovensko, 1910). I se zřetelem na jejich žánrovou rozmanitost je zřejmé, že se významově překrývají. Slovakofilský narativ přelomu století v sobě nese několik specifik, která jsou ojedinělá ve srovnání s jinými českými cestopisy lokalizovanými mimo Slovensko, nebo např́íklad s jinojazyčnými cestopisy o Slovensku v daném období (např́klad mad'arsky či německy psané cestopisy). Na jedné straně je to slovakofilský postoj namírený vůči koloniálním praktikám národnostně i jazykově sjednocených Uher před první světovou válkou. $V$ teorii postkolonialismu bychom mohli aktivity slovakofilů v této fázi identifikovat jako antikoloniální, otevřeně se vymezující vi̊či politice jednotných Uher. Nelze však přehlédnout, že se v jejich pomoci Slovensku rodí už nová komunikační situace s aspekty koloniálního vztahu, které najdou své konkrétní uplatnění po vzniku společného státu. Na pozadí širokého uplatňování česko-slovenské vzájemnosti vykrystalizoval metaforický obraz bratrství, modelovaný na principu superiority jako paternalismus. ${ }^{5}$

Na utváření konkrétní podoby cestopisného narativu mělo klíčový vliv takzvané předporozumění. ${ }^{6}$ Čeští cestovatelé přijižždějí na Slovensko před první světovou válkou s přibližně stejnou mírou tohoto předporozumění, ale především se stejným ideologickým přesvědčením. Jejich postoj byl poznamenán paternalistickým vztahem ke Slovensku a prosazuje se v próze českých autorů ještě hluboko v následujícím období první Československé republiky. Slovakofilský narativ v jedné ze svých textových vrstev pracuje se silně stereotypním obrazem dějin, jehož smysl se príliš nemění. Ve třech krocích vzniká nacionální zkratka města: počátky města, Prešpurk L'udovíta Štúra a město s mad'arsko-německým obyvatelstvem. Pozitivní pozornost cestovatelů poutá zejména obraz Prešpurku, který v souvislosti s L'. Štúrem už nevstupuje do negativních konotací z dob kodifikace spisovné slovenštiny. Vztahy mezi Čechy a Slováky jsou směrem do minulosti idealizovány.

5 Zatímco u Pokorného můžeme nalézt zmínku o bratrské pomoci bez vyhrocené superiority silnějšího etnika nad tím slabším, tudiž ve smyslu obecně uplatňované lidskosti a porozumění, Kálal již běžně používá obraz staršího a zkušenějšího bratra, který musí pomoci tomu slabšímu.

6 V souvislosti s deskripcí jednotlivých cestopisných narativů se ukazuje jako produktivní sledovat charakter takzvaného předporozumění, se kterým cestovatel-autor přijíždí na Slovensko. K pojmu předporozumění viz např́íklad Passia (2016: 251-260), nebo šířeji J. Tancer: „Pri vytváraní predstavy o meste zohráva dôležitú rolu celý rad d'alších okolností - osobnost' pozorovatel'a, jeho vek, pohlavie, kultúra, z ktorej pochádza, vzdelanie, profesia, osobné skúsenosti, záluby, predsudky, momentálna nálada a pod.“ (Tancer 2013: 15). 


\section{2. Od slovakofilství k narativu čechoslovakismu}

Na př́kladu Klímova bedekru (Vlakem pres Slovensko, 1910 a 1920) ${ }^{7}$ je primárně vidět, jakým zpo̊sobem autoři cíleně přepisovali text ve jménu aktuální poptávky nově vzniklé republiky. Estetické vidění těchto textů se však nemění, změna probíhá jen na úrovni ideologických postojů. Zatímco ještě v předpřevratovém období se řadil Klímův bedekr k okrajovým aktivitám českých slovakofilů, které nebyly nijak garantovány státem, tak vydání z roku 1920 patří z hlediska interpretace vztahu Čechů ke Slovensku mezi takzvané státotvorné. ${ }^{8}$ Neutrální obrazy jsou v cestopisu po roce 1918 vytěsňovány prvky koloniální rétoriky: „Největší důležitost pro Československou republiku má Bratislava, jakožto hlavni náš prístav dunajský, spojujicí náš vnitrozemský stát veletokem dunajským s mořem" (Klíma 1920).9

Prešpurk/Bratislava zaujímají v obou vydáních Klímova bedekru spíš okrajové místo. Obligátní názvový posun od Prešpurku k Bratislavě má rovněž konsekvence na ose cizí a naše. Bratislava není už cizím městem s převažujícím německým a mad'arským etnikem, ale městem s celou řadou výrazných českých stop zakonzervovaných v historické i kulturní oblasti Bratislavy. ${ }^{10}$ Na prahu dvacátých let se rázem stává městem vzdělanosti a kulturnosti. Českým čtenářům přibližuje město prostřednictvím autorit české vědy svázaných s městem v minulosti. Rozšiřuje tak starší obraz města o univerzitní rozměr, který dodává Bratislavě moderní ráz čerpající z demokratických základů první republiky.

Slovakofilský narativ udržují hlavně bedekry, které krátce po vzniku republiky neměly ambici v dramatickém začátku zrodu psát nový (jiný) příběh o Slovensku a Bratislavě. Dokladem toho je Klímovi žánrově blízký bedekr Slovenskem od Karla Václava Adámka z roku 1921. Oproti svým předchůdcům precizuje historický obraz města, který je v rovině faktografické i ideologické mnohem více informačně nasycený. Bratislavu neopomíjí představit jako moderní město, které se př́znakově zrodilo v okamžiku, kdy se do ní přestěhovala státní správa. Aktuální rozměr Bratislavy se prolíná s mohutnou minulostí města, v níž Češi zanechali svůj otisk. Kulturní rozměr města naprosto konstruuje v souvislosti s novou ideou čechoslovakismu, která předpokládá existenci nejen československého jazyka, ale také československých časopisů, československého knihkupectví a podobně. Autor se vyhýbá použití adjektiva „slovenský“, prakticky ke slovenské identitě neodkazuje. $Z$ textu vystupuje dobově příznačný bohemocentrický přístup.

7 Původně cestopis vyšel v rámci vydávání Slovenské ćitanky (Klíma 1910). Aktualizované vydání cestopisu po roce 1918 je dostupné online (Klíma 1920).

8 Za tím si lze představit podporu legitimizace vzniku první Československé republiky, která se opírala o ideu čechoslovakismu vycházející z umělého konstruktu takzvaného československého národa. Také na úrovni literární produkce (nejen umělecké, ale rovněž v oblasti vědy) mělo dojít k podpoře stěžejní ideologie první republiky.

9 S takřkka totožným dobyvatelským postojem pracuje ve svém románu Nová země (1927) Jan Václav Rosůlek, když vyjmenovává, co všechno Češi získají začleněním Slovenska do společného státního útvaru: „Mincovnu. Železárny. Cukrovary. Prešpurek. [...] Nevíš ani, co bychom získali! Světové lázně! Paroplavbu do Černého moře" (Rosůlek 1927: 22).

10 Během bratislavských studií se zde seznámil František Palacký s Pavlem Josefem Šafaříkem, který později prožil významnou část svého osobního i pracovního života v Praze. Právě příklad Šafaříka se na stránkách prvorepublikových románů objevuje jako pozitivní obraz literarizované česko-slovenské vzájemnosti 19. století. 
Cestovní bedekry i umělecké cestopisy měly primárně motivovat k cestování na Slovensko. Jejich další intencí však bylo přiblížit českým čtenářưm krajinu, která byla mnohými právem vnímána jako cizí, ale zároveň byla od osmdesátých let 19. století přibližována v terminologii slovakofilů jako bratrská krajina, tedy prostor blízký s jistým potenciálem krajiny domovské. Tento paradox prožívání Slovenska jako blízkého i cizího prostoru zároveň zrcadlí nejlépe Bratislava, která se stala nejméně osvojeným prostorem českých cestopisů o Slovensku. Nový obraz Bratislavy se začal formovat až mnohem později na přelomu dvacátých a třicátých let. Na pozadí doživajících snah českých slovakofilů se v meziválečném období rodila nová podoba česko-slovenských vztahů. V souvislosti s poznáváním tradiční kultury Slovenska upozornil Ján Smrek na př́stup Karla Plicky, který označil za dobrý př́klad česko-slovenských vztahů v nové republice (Kapráliková 2017: 137). Ani pozitivní příklad Plickovy tvorby nepřekonává zavedené myšlenkové stereotypy v komunikaci s českými čtenáři. Po roce 1918 chtěla řada představitelů české kultury sama poznat a zažít Slovensko. Sledováním jejich cest a cestopisných záznamů je možné formulovat několik základních prvorepublikových narativů o Bratislavě (a Slovensku). Vedle slovakofilského narativu se však začínají prosazovat i jeho antislovakofilské podoby promlouvající spíš o podobách česko-slovenské nevzájemnosti. ${ }^{11}$

\subsection{Sociální narativ}

Slovakofilské tradici byla nejbliže Marie Majerová, jejíž soubor cestopisných reportáží a povídek Ze Slovenska (1920) vyšel jen krátce po vzniku republiky. Cestu na Slovensko popisuje formou paradoxu na ose cizí a naše, ve kterém je „neznámá země zároveň „řekou domáckou“, a její pout'se postupně formuje do „nečekaného“ poznávání vlasti. $\mathrm{V}$ jejím postoji se odráží ještě soubor pevně zakořeněných formálních i tematických postupů, které se formovaly v českém prostředí zhruba od osmdesátých let 19. století jako slovakofilská tradice. Spojujícím narativním gestem je nesouhlas s vizí jednotné uherské politiky, proto autorka z proudu „domácké řeky" vyloučila všechna jiná etnika než slovenská. Na př́kladu odrodilé Slovenky, která zapomněla na svůj rodný jazyk, když se provdala za Mad'ara, formuluje známý obraz romantismu, ${ }^{12}$ který se opírá o tradiční pilíře konstruování obrazu mad'arónů využívané již ve starších textech českých autorů. Své prozaické texty s cestopisným jádrem lokalizovala do sociálně slabých oblastí na Oravě a Považí, kde pomocí motivu alkoholu jako destruktivního elementu zobrazila rozsah chudoby a zaostalosti této části nově se formující vlasti: „Opilec za bilého dne! A nikdo se za nimi neohlédne, nikdo se nepohorší, ba nikdo se ani neposměje! Je to zde tedy věc zcela běžná, samož̌ejmá, denní!“ (Majerová 1920: 79-80). Zřejmá je její blízkost k reportážím předpřevratového slovakofila Ivana Hálka, který takřka sociografickou metodou zachycuje Kysuce na prahu 20. století. ${ }^{13}$ U obou autorů příznakově

11 Viz podoby vzájemnosti a nevzájemnosti v knize Anny Zelenkové Medzi vzájomnostou a nevzájomnostou (2009).

12 Také A. Zelenková upozorňuje na romantický rámec některých cestopisných textů M. Majerové (Zelenková 2009: 120).

13 Knižně vyšly Zápisky slovenského lekára I. Hálka až v roce 1932, ale průběžně je autor publikoval časopisecky ještě před rokem 1918 na stránkách masarykovského časopisu Čas. 
240 chybí zobrazení Bratislavy, stává se jakýmsi nulovým morfémem jejich tamního působení a putování, které bylo výrazně selektivní. Etnické složení Bratislavy se po vzniku první republiky jen pozvolna proměňovalo a $M$. Majerová vyloučila ze svého vyprávění o Slovensku zejména etnické menšiny Mad'arů a Němců. $V$ daném pohledu byla Bratislava pro Majerovou etnicky př́liš nejednoznačná.

\subsection{Ve službách vlasti: narativ deziluze}

K autorům, kteří cestovali na Slovensko krátce po vzniku republiky, patřil také Jakub Deml. ${ }^{14}$ Jeho zobrazení Slovenska jako literární krajiny se rodilo nejen z existence nového společného státu, ale v rovině estetické také z emocionálního napětí. Proto je v něm možné rozpoznat tolik iracionálních obrazů, jež se sbíhají v několika heterogenních vrstvách do podoby komplikovaného textu nesoucího jednoznačnou výpověd' formulovanou jako rozčarování. ${ }^{15}$

Demlovo poznávání Slovenska před samotnou cestou je doloženo ve starších svazcích Šlépějí ${ }^{16}$ Formulovalo se v diskusích s legionáři, četbou slovakofilských knih o Slovensku až po záměr pojmout cestu jako studijní pobyt se sběrem slovenských pohádek, pověstí a lidových písní v intencích sběratelské činnosti Boženy Němcové ze začátku padesátých let 19. století. V tomto smyslu Demlova komunikace s rozličnými dobovými diskursy cestopisného žánru obsáhla celou šiřri obrazů Slovenska. Demlovo očekávání bylo vysoké. Jeho pobyt na Slovensku byl však nečekaně krátký, odehrál se během několika málo měsíců krátce po vzniku první republiky a skončil velkým rozčarováním. Zklamání se dotýká nejen konstruování obrazu Slovenska v rámci nového státního celku, ale v dílčím pohledu se vztahuje také k okrajovému zachycení Bratislavy, kam autor soustředil státní moc. Bratislavu sice ze svého vyprávění o Slovensku zcela nevytěsnil, jak to učinila M. Majerová přibližně ve stejnou dobu, ale obraz města nabývá v textu temných kontur, které mu znepřijemňují až znemožňují slovenský pobyt.

Jádro autorovy slovenské zkušenosti tvoří cestopisný text s příznačným názvem $Z$ mého okovu, v němž rezonují klíčové třecí plochy plynoucí z politiky jednotné Československé republiky a bohemocentrického př́stupu, který přichází do konfliktu s odlišným vnímáním elementárních lidských hodnot (jednou z nich byla také víra a role církve). Na stránkách Demlových cestopisných postřehů vzniká historicky podmíněná reprezentace, která nijak neparticipuje na starším slovakofilském obrazu. Jak také v osmém svazku Šlépějí zprostředkovaně kontextualizuje sám autor: „Jeden z mých prátel, kterýv Topolčankách četl rukopis ,Z mého okovu,

14 J. Deml přijel na Slovensko s konkrétním posláním. Byl pověřen státní mocí, aby z pozice představitele nově vzniklé Československé republiky a jako nový správce připravil zámeček („,kaštiel“) v Topolčiankách na př́ijezd prezidenta. $V$ postkoloniální kritice by tento krok měl jednoznačnou interpretaci s dostatečným množstvím preobrazů/pretextů. Vývoj česko-slovenských vztahů se výrazně vzdálil slovakofilské tradici a prosazovanému paternalistickému postoji ke Slovensku. $\mathrm{V}$ krajní podobě se namísto něj prosazuje vztah kolonizátora k podř́zenému etniku.

15 Charakter cesty zachytil ve dvou svazcích Šlépěji z roku 1920 a 1921. Samostatně je vydal jako knihu až v roce 1927 pod názvem $Z$ mého okovu.

16 Viz čtvrtý a šestý svazek Šlépěji z roku 1919, ve kterých J. Deml nejprve zmiňuje své růžové plány o Slovensku (Deml 1919a: 46), a později je konkretizuje jako studijní cestu a kulturní misi (Deml 1919b: 285). V šestém svazku jsou široce zaznamenány Demlovy př́ípravy na cestu, jejichž součástí je i studium aktuální situace na Slovensku: dopis českého legionáře bojujícího proti Mad’arům na Slovensku, nebo četba Kálalových knih o Slovensku. 


\subsection{Ve službách vlasti: idylický narativ}

Cestopisná tvorba Karla Čapka se v meziválečném období stala jistým fenoménem, který měl dosah na precizaci významu i výrazu v oblasti daného žánru. Jeho cestopisy se také jako jedny z mála staly součástí takzvaného literárního kánonu, a ani v Čapkově autorském kontextu je nelze označit za marginální. Slovensko však vstupuje do jeho cestopisů jen okrajově jako „obrázky z domova“, kam byly cestopisné črty vznikající mezi lety 1926 až 1931 v knižním vydání z roku 1953 zařazeny. Př́íznačné je jejich vřazení mezi „domovské obrázky“, které signalizuje ideologické přesvědčení autora a odkazuje na jeho proživání Slovenska jako domovského prostoru. ${ }^{17}$ Vedle jeho Obrázků z Čech a Putováni po Praze se objevuje třetí kapitola zahrnující vzdálenější část nového domova Obrázky ze Slovenska.

Čapkova cesta po domovině se v souvislosti s modelováním obrazu Slovenska naplňuje ve dvou rovinách. Nejprve jako vzpomínka na harmonickou krajinu Slovenska, kde spolu s rodiči strávil autor své dětství. Podruhé jako důvera v demokracii nově zrozené Československé republiky. Ani jedna z významových rovin se neprolnula s obrazem Bratislavy. Bohužel, cestopisné Putováni po Praze nenašlo svůj slovenský pendant v pomyslném „putování po Bratislavě“. Autor se uchýlil k oslavě prírodních krás a vyjádření obdivu k lidové architektuře a slovenskému folklóru, kde nezbývá prostor pro zachycení života ve městě. Mirna Šolić v souvislosti s Čapkovým zájmem o živý folklór zmiňuje, že jde o lyrické „zachycení ,jinakosti' ve vlastnízemi, která se v menším měřítku podobá Skotsku v imperiální Británii“ (Šolić 2015: 156). Načrtnutá superiorita ve vztahu Čechů ke Slovensku a Čapkovo prožínání Slovenska jako širšího domova s odkazem na jeho dětství řadí autora k zastáncům československé jednoty, která po vzniku republiky nalezla svůj program v konkrétní ideji čechoslovakismu.

Mezi Čapkovy Obrázky ze Slovenska nebyly zařazeny kratší novinové črty a komentáře vycházející rovněž $\mathrm{v}$ Lidových novinách, které by bez zkušenosti Čapka coby „,cestovatele“ nemohly vzniknout. Jedním z nich je Čapkovo zamyšlení nad slovenskou tradicí, které vyšlo pod názvem Co s Martinem? v roce 1931. Autor v něm hovoří o zvláštním poslání Martina a Bratislavy, dvou měst, která představují v souvislosti se slovenskou otázkou odlišnou zkušenost slovenského národa. Obě města se dle Čapka vzájemně potřebují a utvářejí obraz prvorepublikového Slovenska: „Bratislava užsvou polohouje cosijako československá a středoevropskáŽeneva; Martin zavřenýv horském klínu Turčanskézahrádky, přirozenýstřed nejčistších slovenských oblastí: Oravy, Trenčina, Nitranska a Liptova, se zdá predurčen k tomu, aby zůstal strážcem svébytných národnich hodnot slovenských" (Čapek 1931:2). V přirovnání Bratislavy k Ženevě se protínají žrejmě dva významy. První odkazuje na nocionální význam „společnosti národư“ žijících na ploše jednoho města a tvořící pomyslné srdce střední Evropy, druhý pracuje s historicky podmíněnou reprezentací Bratislavy jako města zrozeného z poválečného jednání,

17 Viz komentář z konferenčního sborníku Fenomén cestopisu v literatuře a uměnístřední Evropy: „Podotkněme, že Čapek je v českém prostředí jako spisovatel i díky přátelství s Masarykem vnímán do značné míry jako budovatel, či alespoň rozhodný zastánce existence československého státu“ (Vašut 2015: 273). 
242 kdy zásluhou ženevské Společnosti národů se město stalo součástí první Československé republiky. Čapek v harmonizujícím obrazu Bratislavy jako společnosti

zacátku třicátých let podnikl svoji cestu na Slovensko také český básník, levicový intelektuál, Stanislav Kostka Neumann a postřehy z cesty zachytil na stránkách cestopisného deníku Československá cesta. Deník cesty kolem republiky od 28 . dubna do 28. řijna 1933 (knižně až 1952). Bratislava má v jeho narativu pevně dané místo. Její literární reprezentace na stránkách deníku je determinována odlišnou společensko-politickou situací, která je po víc jak deseti letech od vzniku republiky zasažena slovenským autonomismem. Na Slovensko přijíždí s odlišným předporozuměním než předchozí generace slovakofilů a jejich epigonů. Neumann ve své myšlenkové konstrukci obrazu Slovenska a městského prostoru Bratislavy neuplatňuje ani bohemocentrický postoj aktuální ještě v prvním desetiletí existence Československé republiky. Při vstupu do Bratislavy nahrazuje tradiční obraz města jako domova zeslabujícím výrazem blízkosti

„milované a nikoli cizi. [...] Zalibily se nám tehdy pitoresknost jejího slunného podhradí a ghetta, výraznost některých historických architektur, velkoměstský život a mezinárodníráz. Jsme už tací, že se cítíme nejsvobodnějšími bud'v nezalidnèné prírodě nebo v davu, který mluví mnoha jazyky" (Neumann 1952: 49).

Fascinován městem vytvořil silně stylizovaný obraz Bratislavy jako metropole s bohatým multikulturním životem, který byl podle Neumanna přirozenou součástí historie města. Proto autor bez zaváhání zmiňuje libozvučnost mad'arštiny a s lehkou ironií dodává: „chtěl bych se dokonce naučiti ještě tomuto jazyku, kdyby byl užitečnějši" (Neumann 1952: 65).

Neumann se snaží zasadit obraz Bratislavy do širšího exotického rámce svých cestovatelských zkušeností, proto mu břehy Dunaje připomínají „scenerie na řekách jihoamerických“ (Neumann 1952: 50). Porozumění nachází pro drobné kavárny a hospůdky, kde hraje „cigánský doprovod“. Nekonstruuje sociální ani nacionální obrazy Bratislavy, ale z jeho stránek vystupuje už nová Bratislava, která v sobě nese kulturní otisk velkoměsta oproštěný zejména od dobového nacionalismu. Přísná selekce v konstruování obrazu města vytěsňuje historický obraz Bratislavy, který autor nahrazuje historií kavárenského života.

Na př́kladu Neumannova cestovního deníku se ukazuje posun ve vnímání Slovenska českými intelektuály ve třicátých letech 20. století. Uhranutí folklorem a panenskou horskou př́rodou přichází až za Užhorodem a váže se na literární reprezentaci Podkarpatské Rusi, kterou považuje za „nejpi̊vabnějǐsi ,kolonii západoevropskou“ (Neumann 1952: 145). Pečlivě konstruovaný narativ českých slovakofilů se postupně rozpadá; změnu explicitně pojmenoval v roce $1968 \mathrm{Fe}$ lix Vodička: „Zatímco představa prýrodní bezprostřednosti a lidské plnosti byla v předválečném období spojována se Slovenskem, je v letech třicátých umistována na Podkarpatskou Rus“ (Vodička 1997: 214-224). 
V ironickém modu pracuje s tradicí českých slovakofilů ve své Cestě Slovenskem Josef Váchal, který Slovensko mezi červnem a zář́m roku 1930 také navštívil. Ze slovakofilského narativu mu zůstal blízký jen magický svět pohádek a pověr, pomocí kterého např́klad K. Kálal dokazoval zaostalost, nevědomost a sociální bídu Slovenska. ${ }^{18}$ Poetika Váchalova cestopisu převrací Kálalovu negativní tonalitu vyprávění a na principu lidových pověr otevírá svět iracionality a sarkastického porozumění pro Slovensko. V autorově postoji se promítá dobově nejednoznačná a těžce uchopitelná interpretace okolního světa.

Váchalovo předporozumění bylo formováno řadou starších i mladších textů. Vůči starší tradici se ironicky vymezoval: ,Jako průměrný pozorovatel Slovenska vědèl jsem o něm pouze tolik, že je v něm mnoho lázní, kyselek a hory, [...] znal jsem Slovensko leda z pohádek Boženy Němcovéa některá jeho města z románů Jokaiových“" (Váchal 1998: 58). Jen jakoby mimochodem na ploše jedné věty zachytil víc, než se podařilo v cestopisech jeho vrstevníkům. Obraz Slovenska se v dobovém pohledu J. Váchala formoval na pozadí dvou odlišných kulturně-politických rámců, českého a mad'arského, přičemž součástí jejich národních koncepcí se mělo stát právě slovenské etnikum. Koncem dvacátých let však nevycházejí jen knihy se slovakofilským postojem: do svého deníku si Váchal 13. března 1930 poznamenal: „Dočetl chmurnou Novou zemi Rosůlkovu“ (Váchal 1998: 96), v níž se Jan Václav Rosůlek otevřeně vymezuje vůči slovakofilské tradici zastoupené Kálalem. ${ }^{19} \mathrm{Na}$ ploše Rosůlkova románu vyrůstá obraz Bratislavy v ironickém modu jako města deziluze. J. Váchala Bratislava a její nový velkoměstský život př́iliš nezajímala. Literární obraz Bratislavy je $\mathrm{v}$ jeho cestopisu zprostředkován formou digresivních vyprávění. Jejich zastoupení na ploše cestopisu je jednoznačně marginální, rodí se ze dvou textových rovin. Jednou je vyprávění o Calmetově knize, kde se také nachází příběh o vylodění v Prešpurku, kam Calmet lokalizoval fantastické setkání dvou odvěkých nepřátel, upíra s vlkodlakem. Druhý obraz je součástí příběhů o Slovensku zasazených do minulosti (v části Rozmanité fabule a príhody ze Slovenska). Popisuje v něm nespravedlivé uvěznění tovaryše, který byl okraden v Prešpurku a následně v inscenované části zachráněn proradným jezuitou, kterému od té doby musel sloužit. Společným jmenovatelem zmiňovaných obrazů je fantastický rámec vyprávění, který umožňuje zobrazit Bratislavu jako město nesrozumitelných i nejednoznačných významů, právě tak jako byla Bratislava pro Rosůlka městem deziluze. Z Rosůlkova románu mu implicitně zůstala ironická vrstva textu, která doplňuje iracionální vyprávění a překrývá reálný svět. Váchalova poetika je primárně svázána s horským prostředím, které bohatě produkuje vypravěčský potenciál pro svět iracionality. Ačkoli má cesta reálné kontury, cestovatel se setkává víc s upíry, divoženkami a vlkodlaky než skutečnými obyvateli Slovenska. Váchal tak stvořil iracionální kontrafaktuální svět, který neodpovídá žádné ze zkušeností jeho předchůdců. Dějiny ve starších cestopisech a bedekrech promlouvají formou srozumitelných národních symbolů na pozadí starobylých

18 Explicitně např́klad zde: „Lid slovenský jest ještě hodně pověrčivý“ (Kálal 1903).

19 Druhým textem, který Váchala ovlivnil, byl Masarykův pohled na Slovensko v Čapkových Hovorech $s$ T. G. Masarykem. Jinak Čapkovu cestopisnou tvorbu tvořící dobový kánon daného žánru zesměšňuje a odkazuje k „primitivnímu uměni“ (Váchal 1998:97). 
244 hradů a zřícenin. Váchal neváhá zbořit tento pilír slovenských dějin a nabídnout českým čtenářům alternativní dějiny, např́ílad hrad Strečno zobrazuje mimo zauživané konstrukty národní minulosti jako úkryt pro vlkodlaky. Do popředí se dostávají pověry a démonické př́běhy. Naopak formulování nacionálních výroků v intencích zaužívaných stereotypů vztahujících se k jednorozměrnému vnímání Slovenska jako bezproblémové malebné krajiny přenechává autor s oblibou svému psovi, který ho na cestě doprovází. Autorovi se daří na hraně iracionality podat vlastní zprávu o Slovensku, okrajově také o Bratislavě, v níž estetická funkce překrývá primárně výpovědní hodnotu dobových cestopisů.

V úvodu naznačený distanc od narativu změny v souvislosti se zobrazováním Bratislavy v českých cestopisech po vzniku Československé republiky upozorňuje na velmi silnou slovakofilskou tradici s kontinuitou hluboko do dvacátých let. Repertoár slovakofilských stereotypů je v počátcích existence první republiky ještě velmi produktivní. Z hlediska žánru se naplňuje i vyčerpává v bedekrech a sociálním variantu cestopisu. Jen pozvolna se prosazuje ideologie čechoslovakismu, která nasycuje původní slovakofilský narativ o další významy. Vedle těchto dvou zaužívaných myšlenkových schémat a obrazů vztahujících se ke Slovensku a Bratislavě se v tvorbě českých autorů, zejména od třicátých let 20. století, konstruuje už obraz zcela nový, neakceptující starší slovakofilský narativ. Na jeho počátku stál Demlův cestopis, v jehož narativu deziluze se autor postavil mezi prvními vůči opakování myšlenkových stereotypů a imagologických konstruktů založených předcházející generací slovakofilů. K dalším významovým posunům dochází od začátku třicátých let především zásluhou nonkonformního autora J. Váchala. Oba cestopisné varianty reprezentují v meziválečném období odlišný vztah autorů ke Slovensku. Společná je iracionalita jejich výpovědi, která odvádí pozornost od faktuálního poznávání sledovaných prostorových entit. Básnické vidění je v obou textech propojené se silným obrazným jazykem, díky kterému mají cestopisy potenciál rezonovat i v dnešním čtenářském prostředí. Ze sledovaného korpusu cestopisných textů meziválečného období je zřejmé, že poznávání Slovenska se probojovávalo do pozice klíčového tématu cestopisné literatury jen zvolna. Naprosto marginálně pak vyznívá zájem o pochopení Bratislavy jako místa s konkrétní kolektivní pamětí.

\footnotetext{
Pramene

ADÁMEK, Karel Václav, 1921. Slovenskem. Díl I. V Praze: Nakladatelství J. Otto, s. 17-45. ČAPEK, Karel, 1953. Obrázky z domova. Praha: Československý spisovatel. DEML, Jakub, 1919a. Šlépěje 4. Ve Šternberku na Moravě: Jakub Deml. DEML, Jakub, 1919b. Šlépěje 6. V Tasově: Jakub Deml. DEML, Jakub, 1920. Šlépěje 7. V Bělé u Bezděze v Čechách: Jakub Deml a Pavla Kytlicová. DEML, Jakub, 1921. Šlépěje 8. V Tasově na Moravě: Jakub Deml a Pavla Kytlicová.

HÁLEK, Ivan, 1932. Zápisky slovenského lekára. Žilina: [s. n.].

KLÍMA, Stanislav, 1910. Vlakem přes Slovensko. III. oddíl. Část cestopisná. In Slovenská čitanka. Praha: Emil Šolc, s. 39-126.

MAJEROVÁ, Marie, 1920. Ze Slovenska. Praha: Holubice.

NEUMANN, Stanislav Kostka, 1952. Československá cesta. Deník cesty kolem republiky od

28. dubna do 28. ř́ina 1933. Praha: Nakladatelství Svoboda.

ROSŮLEK, Jan Václav, 1927. Nová země. Román. Praha: Družstevní práce.
} 
STLOUKAL, Karel, 1927. Riegrovy zápisky o Slovensku v r. 1847. Bratislava, roč. 1, č. 3-4, 245 s. 532-537.

VÁCHAL, Josef, 1998. Deníky: výbor z let 1922 - 1964. Praha - Litomyšl: Paseka.

VÁCHAL, Josef, 2012. Jos. Váchala cesta Slovenskem s A. Calmetem Ord. S. B. aneb Theorie wampyrismu. [Praha]: Gallery.

\section{Literatúra}

KAPRÁLIKOVÁ, Monika, 2017.Za hranice provincie. Ján Smrek a jeho E/elán. Bratislava: Elán. ISBN 978- 80-96959-15-0.

PASSIA, Radoslav, 2016. Potešenie z karpatských hôr. Premeny motívu vo vybraných českých cestopisoch z 19. storočia. In SOLAK, Elżbieta - POPIOŁEK, Barbara - TODOROVIĆ, Bojana, ed. Mate przyjemności: katalog stowiański. Kraków: Wydawnictwo Scriptum, s. 251-260. ISBN 978-83-65432-34-6.

ŠOLIĆ, Mirna, 2015. Slovo a obraz: Karel Čapek a žánr cestopisu. Olomouc: Vydavatelství Filozofické fakulty Univerzity Palackého. ISBN 978-80-87895-26-9.

TANCER, Jozef, 2013. Neviditelnémesto. Prešporok/Bratislava vcestopisnejliteratúre. Bratislava: Kalligram. ISBN 978-80-8101-665-3.

VAŠUT, Tomáš, 2015. Karel Čapek ve stínu dvouhlavého orla. In HRABAL, Jiří, ed. Fenomén cestopisu v literatuře a uměni středni Evropy. Olomouc: Univerzita Palackého, s. 269-286. ISBN 978-80-244-4876-3.

VODIČKA, Felix, 1997. Český literární mýtus o Slovensku. In PATERA, Ludvík - CHMEL, Rudolf, ed. Kontext české a slovenské literatury. Antologie českých a slovenských textů 1830 - 1989. Praha: Karolinum, s. 214-224.

ZELENKOVÁ, Anna, 2009. Medzi vzájomnostou a nevzájomnostou. Sondy do česko-slovenských a slovensko-českých literárnych vztáahov. Praha-Nitra: Slovanský ústav AV ČR-Filozofická fakulta Univerzity Konštantína Filozofa. ISBN 978-80-8094-648-7.

\section{Elektronické zdroje}

ČAPEK, Karel, 1931. Co s Martinem? Lidové noviny [online]. Praha, roč. 39, č. 494 (3. 10. 1931), s. 2 [cit. 12.1. 2021]. Dostupné z: https://www.lidovenoviny.cz/ctecka. aspx?d=03.10.1931\&e=LN1\#strana=2

KÁLAL, Karel, 1903. Na krásném Slovensku [online]. Praha: Jos. R. Vilímek [cit. 16. 1. 2021]. Dostupné z: https://zlatyfond.sme.sk/dielo/5027/Kalal_Na-krasnem-Slovensku/1

KLÍMA, Stanislav, 1920. Ilustrovaný průvodce po Slovensku [online]. Praha: Šolc a Šimáček. [cit. 30. 12. 2020]. Dostupné z: https://zlatyfond.sme.sk/dielo/5175/Klima_Ilustrovany-pruvodce-po-Slovensku

PhDr. Jana Pátková, Ph.D.

Katedra středoevropských studií

Filozofická fakulta Univerzity Karlovy

Nám. Jana Palacha 2

11638 Praha 1

Česká republika

e-mail: jana.patkova@ff.cuni.cz 